\title{
Ruptured Lung Cyst Hydatid: A Case Report
}

Rüptüre Akciğer Kist Hidatiği: Bir Olgu Sunumu

\author{
Eren Usul ${ }^{1}$, Mehmet Hilmi Höke', (D) Anıl Gökçe ${ }^{2}$ \\ 1-Sincan Dr Nafiz Korez Public Hospital, Emergency Medical Service, Ankara 2-Ankara Şehir Hastanesi, Department of \\ Thoracic Surgery, Ankara
}

\begin{abstract}
Hydatid cyst is a parasitic disease that ongoing in visceral organs with cyst formation particularly by Echinococcus granulosus. The primarily effected organ is liver by hydatid cyst while the secondary is lungs. Chest pain, dyspnea, fever, weakness, cough, hemoptysis and phlegm are symptoms of pulmonary cystic hydatitosis in addition patients can be asymptomatic. The clinical symptoms differ to location and size of cyst. Herein, we aimed to report 30-year-old-woman having ruptured pulmonary cystic hydatitosis admitted to emergency department with cough, phlegm, dyspnea and fever.

ÖZET

Kist hidatik özellikle Echinococcus granulosus larva formları tarafindan iç organlarda kist oluşumu ile seyreden paraziter bir hastalıktır. Kist hidatik en sik karaciğeri, ikinci sırada akciğeri etkiler. Göğüs ağrisl, nefes darlığı, ateş, halsizlik, öksürük, hemoptizi ve balgam akciğer kist hidatiğinin semptomlar iken hastalar asemptomatik seyredebilir. Klinik belirtiler kistin yerleşimine ve büyüklügüne göre değişir. Biz bu olgu ile acil servise öksürük, balgam, nefes darllğı ve ateş şikayetleri ile başvuran 30 yaşındaki bir kadında gelişsen rüptüre akciğer kist hidatiğini sunmayı amaçladık.
\end{abstract}

Key Words:

Cysy Hydatid,

Lung

Anahtar Kelimeler:

Kist Hidatik,

Akciğer

\section{INTRODUCTION}

Hydatid cyst is a parasitic disease with cyst formation in the internal organs, and the most common causative agent in humans is E. granulous (1). The most common hydatid cyst is located in livers and the second most common in the lungs. Lung involvement is more common at a young age. Hydatid cyst of the lung is generally known as asymptomatic (2). Cyst hydatid cases with lung involvement may present with symptoms such as cough, nonspecific fever, chest pain, dyspnea, side pain, rock water expectation, and hemoptysis (3). In some patients, the diagnosis is made by the occurrence of compression-related symptoms or complications. Cyst rupture is known as one of the complications (4). Cyst rupture may be spontaneous or iatrogenic (5). We aimed to present a case of hydatid cyst of the lung.

\section{CASE PRESENTATION}

A 30-year-old female patient was admitted with complaints of shortness of breath, cough, sputum production, fever, and side pain. On physical examination, general condition was moderate to good, and respiratory sounds were decreased in the left hemithorax by listening, and no pathology was found in other systemic consultations. Vital symptoms of the patient are fever $39^{\circ} \mathrm{C}$, blood pressure 110/70 $\mathrm{mmHg}$, pulse $110 / \mathrm{min}$, so2 (oxygenated) $88 \%$, respiratory rate was $24 / \mathrm{min}$. Hb $11.5 / \mathrm{gr}$; WBC $29,000 / \mathrm{mm}^{3}$, PLT $158,000 / \mathrm{mm}^{3}$ was measured at laboratory tests. On chest $\mathrm{X}$-ray, pneumothorax on the left lung and accompanying circular air-fluid level were observed. (Figure a). On computed tomography of the patient, a near-total air cyst in the left hemithorax, pleural effusion, and germinative membrane appearance (water lily symptom) suggesting ruptured hydatid cyst in the lower segments were observed. (Figure b). Surgical treatment was planned for the patient consulted with thoracic surgery. The patient underwent thoracotomy, and the cystotomy+capitonage technique was performed. No intraoperative complications were determined. The patient was discharged on the 5th postoperative day (Figure c). Oral albendazole treatment was started.

\section{DISCUSSION}

The word hydatid comes from the Latin phrase hydatids, which means water drops (6). Hydatid cyst is an endemic disease in our country that maintains its importance (7). Generally, $60 \%$ of the patients have hydatid cysts in the liver and 30\% in the lung, usually solitary in the lung. It can be multiple in 15-30\% of lung cysts. Symptoms of the patients depend on the location and size of the cyst $(4,5)$. The cyst is asymptomatic if it is not ruptured, is peripherally located, and is small. Large cysts usually produce compression symptoms. The first symptom in patients is a dry cough. Bloody sputum may be observed in cysts placed in central. Some patients may have acute chest pain as well as mild pain. With the opening of the cyst to the bronchus, water, and parts of cysts may come from the patient's mouth (4). Also, dyspnea and bronchospasm may be observed due to some un expectorated germinative membrane parts blocking the trachea. Peripherally located cysts may cause chest pain due to pleural irritation, and those with diaphragmatic neighborhood may cause abdominal pain (4). If the ruptured cyst is infected and there is not 

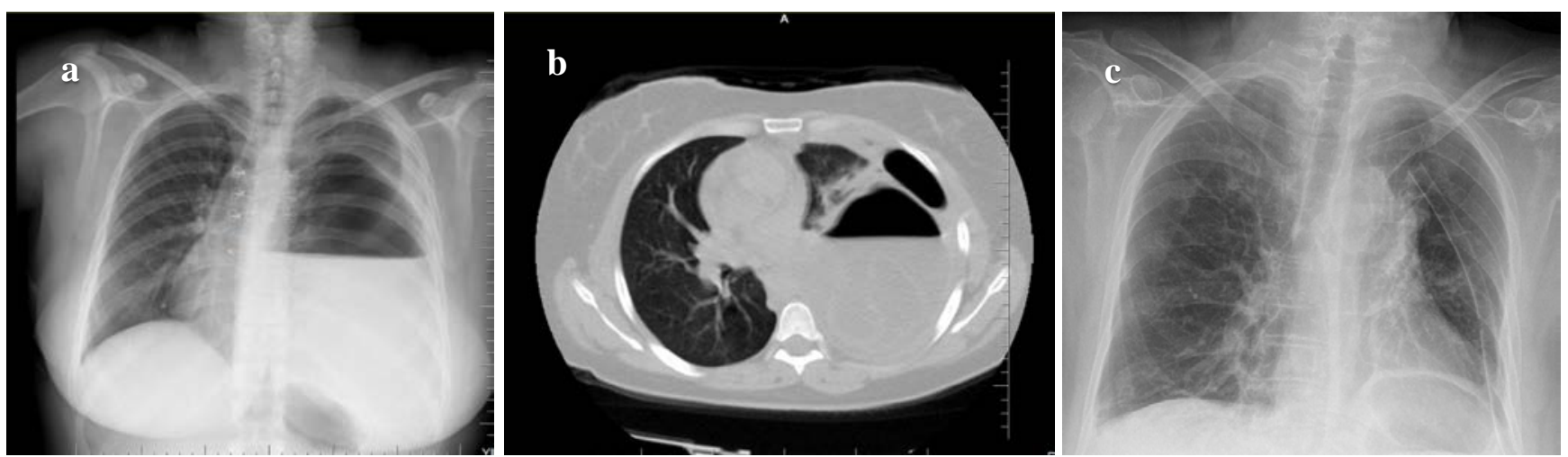

Figure:

a) X-ray, pneumothorax on the left lung and accompanying circular air-fluid level

b) Computed tomography of the patient, a near-total air cyst in the left hemithorax, pleural effusion and germinative membrane appearance (water lily symptom) suggesting ruptured hydatid cyst in the lower segments

c) X-ray after surgery

enough drainage, fever, and purulent sputum can be observed. Similar complaints in many patients presenting to emergency services suggest that hydatid cysts should be considered in the differential diagnosis. Total pneumothorax and related symptoms may be observed if the cyst is located in the periphery and opens into the pleura (1). However, if the patient has pleural adhesion, clinical complaints may be less observe less.

Our case also had cough and fever complaints. Depending on the location of the cyst, Horner Syndrome or Vena Cava Superior Syndrome may be observed. Hydatid cyst rupture may be spontaneous, traumatic and iatrogenic, as well as cough or cyst-wide growth may occur. It was reported that the incidence of rupture was $27 \%(n=90)$ in 326 cases of pulmonary hydatid cysts examined by Balci and et al. (8).

The diagnosis of pulmonary hydatid cyst is usually diagnosed by chest radiography (9). Thoracic CT is helpful in diagnosis. A chest X-ray shows a ruptured cyst as a cavitary lesion with an air-fluid level. (10) In pleural rupture, hydropneumothorax image may occur, and germinative membrane floating in the pleural space may be seen. In our case, thorax tomography was taken after suspicion of air-fluid level and cystic lesion in the left hemithorax on the chest X-ray. In some patients, the persistence of air leakage from the chest tube inserted with suspicion of pneumothorax, non-expanding of the lung, and radiological parenchymal cavitary lesion support the diagnosis. The primary treatment of pulmonary hydatid cyst is surgery (11). Intact cysts should be operated immediately due to the risk of infection and rupture. Even if the parasite inside the cyst is dead, the remaining germinative membrane should be removed by the operation as it may be the source of infection. Today, the aim of surgical treatment is removing the cyst and germinative membrane and avoiding contamination (11).

Currently, parenchymal preservative surgical methods (enucleation, cystotomy-capitonage, pericystotomy, and wedge resection) are used in hydatid cyst surgery. In our case, we applied the cystotomy-capitonage technique. Respective surgery may be performed if more than $50 \%$ of the lobe is devastated-this ratio changes between $10-20 \%$ in various series. There is a coexistence of lung and liver cyst in $4-18 \%$ of hydatid cyst cases. Surgical mortality and morbidity rates are reported as $0-3.3 \%$ and $6-20 \%$, respectively. The morbidity rate is higher in ruptured hydatid cysts than intact cysts (12). Prolonged air leakage and wound infection are the most common complications in the postoperative period. Also, major complications such as empyema, residual cavity development may occur. Postoperative recurrence rate changes between $0.6-1.7 \%$ in various series (13). We think that reason for this situation is antibiotherapy (albendazole) in the postoperative period. However, it is recommended that liver toxicity and neutropenia effect of albendazole should not be ignored during the following-up of patients treated albendazole. Also, antibiotherapy has an essential role in the prevention of recurrences (14).

\section{CONCLUSION}

Hydatid cyst is a common parasitic disease in our country. Hydatid cysts with lung involvement can be diagnosed easily by radiological methods. We conclude that pulmonary cyst hydatid should be considered in the differential diagnosis in patients consulting to emergency services with complaints of cough, shortness of breath, nonspecific fever.

\section{Conflicts of Interest}

All other co-authors have no conflicts of interest.

\section{REFERENCES}

1. Jenkins DJ, Romig T, Thompson RC: Emergence/re-emergence of Echinococcus spp. - a global update. Int J Parasitol. 2005; 35:1205-19.

2. Mora. Sayek İ. Kist Hidatik Hastalığı: Klinik Yönleri. Altıntaş N, Tınar R, Çoker R (eds). Hidatoloji Derneği Yayınları, İzmir 2004:141147. 
3. Santivanez S, Garcia HH. Pulmonary cystic echinococcosis. Curr Opin Pulm Med. 2010;16:257.

4. Köktürk O, Gürüz Y, Akay H ve ark. Toraks Derneği Paraziter Akciğer Hastalıkları Tanı ve Tedavi Rehberi 2002. Toraks. 2002;3:1-16.

5. Bagheri R, Haghi SZ, Amini M, et al. Pulmonary hydatid cyst: analysis of 1024 cases. Gen Thorac Cardiovasc Surg. 2011;59:105-9.

6. McManus DP, Zhang W, Li J, Bartley PB. Echinococcosis. The Lancet. 2003; 362:1295-304.

7. Cobanoğlu U, Sayır F, Mergan D. The results of radiological and serological screening in individuals sharing the same living space as patients with hydatid cysts. Turkiye Parazitol Derg. 2012; 36:65-70.

8. Balci AE, Eren N, Eren S, Ulku R. Ruptured hydatid cysts of the lung in children: clinical review and results of surgery, Ann Thorac Surg. 2002;74(3):889-92

9. Köktürk O. Akciğer hidatik kist hastalığı. In: Ekin N, Uçan ES eds. Solunum Sistemi Enfeksiyonları. Ankara, Turgut yayıncılık, 2001:557604.

10. Erdem CZ, Erdem LO. Radiological characteristics of pulmonary hydatid disease in children: less common radiological appearances. Eur J Radiol. 2003;45:123-8.

11. Dakak M, Caylak H, Kavakli K, Gozubuyuk A, Yucel O, Gurkok S, Sapmaz E, Genc O, Cubukcu S, Tanyuksel M. Parenchyma-saving surgical treatment of giant pulmonary hydatid cysts. Thorac Cardiovasc Surg. 2009; 57(3):165-8.

12. Kabiri EH, El Maslout A, Benosman A. Thoracic rupture of hepatic hydatidosis (123 cases). Ann Thorac Surg. 2001;72:1883-6.

13. Ozyurtkan MO, Balci AE. Surgical treatment of intrathoracic hydatid disease: a 5-year experience in an endemic region. Surg Today. 2010;40(1):31-7.

14. Bagheri R, Haghi SZ, Amini M, Fattahi AS, Noorshafiee S. Pulmonary hydatid cyst: analysis of 1024 cases. Gen Thorac Cardiovasc Surg. 2011 Feb;59(2):105-9. 